\title{
ANALISIS PELAKSANAAN AKAD MURABAHAH MENURUT FATWA DSN MUI NO:04/DSN-MUI/IV/2000 TENTANG MURABAHAH DI KOPERASI SYARIAH MASJID BESAR TEGALKALONG SUMEDANG
}

\author{
Abdul Hamid \\ Sekolah Tinggi Agama Islam (STAI) Sebelas April Sumedang \\ Email: meed.abd@gmail.com \\ Fitri Syifa Fauziah \\ Sekolah Tinggi Agama Islam (STAI) Sebelas April Sumedang \\ Email : Fitrifauziah128@gmail.com
}

\begin{abstract}
Abstrak
Tujuan dari penelitian ini adalah untuk mengetahui penerapan . akad Murabahah secara teoris dan praktis di Koperasi Syariah Masjid Besar Tegalkalong. Penelitian ini menggunakan pendekatan kualitatif dengan metode studi kasus serta mengumpulkan informasi secara terinci dan mendalam dengan menggunakan beberapa prosedur pengumpulan data selama periode tertentu. Hasil penelitian ini menunjukkan bahwa pada umumnya praktik akad Murabahah di Koperasi Syariah Masjid Besar Tegalkalong sudah sesuai dengan Fatwa DSN MUI NO:04/DSN-MUI/IV/2000 Tentang Murabahah. Namun ada 2 (dua) point ketentuan fatwa tentang murabahah yang belum sesuai dengan praktik yang dijalankan oleh pihak Koperasi Syariah Masjid Besar Tegalkalong, yaitu, . pembelian barang diwakilkan oleh anggota, dan anggota pun membeli barang atas nama sendiri bukan atas nama koperasi. dan ketika pihak koperasi melakukan akad murabahah, diwaktu yang sama pihak koperasi melakukan akad wakalah dikarenakan pembelian barang diwakilkan oleh anggota dan anggota membeli barang yang telah disepakati sendiri, hal ini berarti akad murabahah dilaksanakan sebelum barang menjadi milik koperasi
\end{abstract}

Kata Kunci: Murabahah; Fatwa DSN-MUI No.04/DSN-MUI/1V/2000; Koperasi Syariah

\begin{abstract}
The purpose of this study was to see the theoretical and practical application of the Murabahah contract at the Tegalkalong Large Mosque Sharia Cooperative. This research uses a qualitative approach with a study method and collects detailed and in-depth information using several data procedures over a certain period. The results of this study indicate that in general the practice of the Murabahah contract at the Tegalkalong Grand Mosque Sharia Cooperative is in accordance with the MUI DSN Fatwa NO: 04 / DSN-MUI / IV / 2000 concerning Murabahah. However, there are 2 (two) points in the fatwa provisions regarding murabahah that are not in accordance with the practices carried out by the Tegalkalong Grand Mosque Sharia Cooperative, namely, the purchase of goods is represented by members, and members who buy goods on their own behalf, not on behalf of the cooperative. and when the cooperative performs a murabahah contract, at the same time the cooperative that carries out the wakalah contract because the purchase of goods is represented by the member and the member buys goods that have been agreed upon by themselves, this means that the murabahah contract is carried out before the goods become the property of the cooperative.
\end{abstract}

Keywords: Murabahah; MUI DSN Fatwa NO: 04 / DSN-MUI / IV / 2000; Sharia Cooperative

\section{PENDAHULUAN}

Perjanjian atau Akad mempunyai arti penting dalan kehidupan masyarakat dan merupakan 'dasar dari sekian banyak aktivitas keseharian kita. ${ }^{1}$ Akad juga merupakan bingkai transaksi dalam ekonomi syariah, karena melalui Akad berbagai kegiatan bisnis dan usaha

${ }^{1}$ Syamsul Anwar, 2007,Hukum Perjanjian Syariah, Rajagrafindo Persada, Jakarta, hlm xiii 
dapat dijalankan. Akad menfasilitasi setiap orang dalam memenuhi kebutuhan dan kepentingannya yang tidak dapat dipenuhinya tanpa bantuan dan jasa orang lain. Karenanya dapat dibenarkan bila dikatakan bahwa akad merupakan sarana sosial yang ditemukan oleh peradaban umat manusia untuk mendukung kehidupannya sebagai makhluk sosial ${ }^{2}$.

Secara etimologi (istilah) akad berasal dari kata al-aqd yang berarti perikatan, perjanjian, persetujuan, dan pemufakatan. Selain itu, al-Aqd juga bisa berarti tali yang mengikat karena adanya ikatan antara orang yang berakad. Ada juga yang mengartikan akad dengan kesepakatan atau hubungan, sebagaimana terdapat dalam kitab fiqih sunnah. .Secara terminologi (istilah) akad adalah "pertalian ijab" (pernyataan penerimaan ikatan) dan kabul (pernyataan penerimaan ikatan) sesuai dengan syariat yang berpengaruh kepada objek perikatan $^{3}$. .Definisi akad dalam arti luas hampir sama dengan definisi akad dari segi bahasa, menurut pendapat ulama Syafi iyah, Malikiyah, dan Hambaliyah, yaitu segala sesuatu yang dikerjakan oleh seseorang berdasarkan keinginannya sendiri, seperti wakaf, talak, pembebasan, atau sesuatu yang pembentukannya membutuhkan keinginan dua orang seperti jual beli, perwalian dan gadai.

Al-Sanhury sebagaimana dikutip Hasbi Ash-Shiddieqy mengemukakan bahwa akad .adalah "perikatan ijab kabul yang dibenarkan syara yang menetapkan kerelaan kedua belah pihak". Selain itu ada juga yang mengatakan bahwa akad adalah "Setiap yang diinginkan manusia untuk mengerjakanya, baik keinginan tersebut berasal dari kehendaknya sendiri, misalnya daam hal wakaf, atau kehendak tersebut timbul dari dua orang misalnya dalam hal jual beli atau ijaroh. ${ }^{5}$

Dari sekian banyak macam akad yang dipraktekan di lembaga keuangan syariah, salah satunya adalah akad Murabahah. .Akad Murabahah adalah transaksi penjuakan barang dengan menyatakan harga perolehan .dan keuntungan yang disepakati oleh penjual dan pembeli. ${ }^{6}$. Murabahah adalah akad jual beli barang dengan harga jual sebesar biaya perolehan ditambah keuntungan yang disepakati dan penjual harus mengungkapkan biaya perolehan barang tersebut kepada pembeli. Definisi tersebut menunjukkan transaksi akad murabahah, tidak harus dalam bentuk pembayaran tangguh (mencicil), melainkan dapat juga dalam bentuk tunai

\footnotetext{
${ }^{2}$ Ibid. hlm 144

${ }^{3}$ Nurhadi, Filsafat Hukum Islam AkadKompilasi Hukum Ekonomi Syariah(Analisis Maqashid Syariah Buku II Tentang Akad) (Jurnal AlAmwal Vol. 6, No. 2, Des 2017) hal 31

${ }^{4}$ Abdul Aziz Muhammad Azzam, Fiqh Muamalat, (Jakarta : Amzah, 2010), hlm. 15

${ }^{5}$ Rahmat Syafei, Fiqh Muee amalah, (Bandung: Pustaka Setia, 2001) hal 43

${ }^{6}$ Sri Nurhayati dan Wasilah, Akuntansi Syariah di Indonesia Edisi 3, (Jakarta: Salemba Empat, 2014), hlm. 174
} 
setelah menerima barang, ataupun ditanguhkan dengan membayar sekaligus dikemudian hari. ${ }^{7}$

Akad murabahah ini adalah bentuk akad yang banyak digunakan oleh di Lembaga Keungan Syariah (LKS). Berdasarkan data OJK penyaluran pembiayaan di bank syariah terbesar melalui pembiayaan murabahah, (sebesar 47,13\%), disusul dengan pembiayaan musyarakah (sebesar 42,46\%), mudharabah (3,995\%), ijarah $(3,15 \%)$, qardh $(2,7 \%)$, dan istishna' (0,55\%). Hal ini juga terjadi di Koperasi Syariah Masjid Besar Tegalkalong Kabupaten Sumedang. Bahkan di koperasi syariah tersebut, sampai saat ini baru menggunakan akad Murabahah dalam melayani kebutuhan anggotanya. Ada sejumlah alasan mengapa. Koperasi Syariah Masjid Besar Tegalkalong menggunakan akad Murabahah dalam melayani kebutuhan anggotanya. karena akad Murabahah dianggap paling mudah dalam operasional dan kepastian keuntungan yang didapat koperasi.

Namun dibalik kemudahan dan kepastian keuntungan tersebut, berdasarkan tinjauan penulis, terdapat beberapa praktek akad murabahah yang masih melenceng dari aturan yang ada khususnya jika mengacu kepada MUI NO:04/DSN-MUI/IV/2000 tentang Murabahah. Untuk itu penulis ingin megetahui pelaksanaan akad murabahah menurut fatwa DSN MUI NO:04/DSN-MUI/IV/2000 tentang Murabahah di Koperasi Syariah Masjid Besar Tegalkalong Sumedang.

\section{METODE PENELITIAN}

Penelitian ini menggunakan pendekatan kualitatif. .Pendekatan kualitatif .dipilih karena pendekatan ini cocok untuk mengamati suatu fenomena yang terjadi .dilingkungan masyarakat. .Oleh karena itu pendekatan kualitatif digunakan oleh penulis untuk meneliti pada kondisi obyek yang alamiah. ${ }^{8}$

Sedangkan metode yang digunakan dalam penelitian ini adalah studi kasus. Secara umum, studikasus merupakan strategi yang cocok apabila pokok pertanyaan suatu penelitian berkenaan dengan "how" dan "why", bila peneliti hanya memiliki sedikit peluang untuk mengontrol peristiwa - peristiwa yang akan dielidiki, dan bilamana focus penelitiannya terletak pada fenomena kontemporer (masa kini) di dalam konteks kehidupan nyata. ${ }^{9}$

\section{HASIL DAN PEMBAHASAN}

\section{Praktik Akad Murabahah di Koperasi Syariah Masjid Besar Tegalkalong Sumedang}

7 Kautsar Riza Salman, Akuntansi Perbankan Syariah Berbasis PSAK Syariah, (Jakarta: Akademia Permata, 2014), hlm. 141

8 Sugiyono. Metode Penelitian Pendidikan: Pendekatan Kuantitatif, Kualitatif, Dan R\&D. (Bandung: Alfabeta, 2014) hal 9

9 Yin, Robert K. 2006. Studi Kasus :Desain dan Metode. (Jakarta. PT. Raja Grafindo Persada. 2006) hal 1 
a. Produk Pembiayaan Murabahah di Koperasi Syariah Masjid Besar Tegalkalong

Berdasarkan hasil wawancara penulis dengan narasumber yaitu Ibu Esih Sukaesih selaku pengelola unit simpanan dan pembiayaan yang dilaksanakan di Kantor Koperasi Syariah Masjid Besar Tegalkalong. Jenis produk penyaluran dana yang ditawarkan di Koperasi Syariah Masjid Besar Tegalkalong adalah produk pembiayaan murabahah. Penyaluran dana pembiayaan Murabahah yaitu pembiayaan dengan prinsip jual beli barang pada harga pokok dengan tambahan bagi hasil yang disepakati, dimana pihak Koperasi selaku penjual dan anggota selaku pembeli. Pembayaran dapat dilakukan secara angsuran sesuai dengan kesepakatan bersama. Pembiayaan ini cocok untuk anggota yang membutuhkan tambahan asset namun kekurangan dana untuk melunasinya secara tunai.

Transaksi pembiayaaan murabahah yang dilakukan di Koperasi Syariah Masjid Besar Tegalkalong Sumedang lebih sering digunakan untuk pembiayaan yang ditujukan kepada anggota untuk tambahan modal dagang dikarenakan lokasi yang dekat dengan pusat pasar sehingga banyak pedagang yang membutuhkan tambahan modal, seperti pembiayaan untuk bahan dagang dan memperluas usaha. Barang yang sering diajukan oleh anggota ialah berupa bahan dagang, fasilitas dagang, barang untuk keperluan sekolah, dan barang untuk kebutuhan pokok seperti rokok, kopi, buku, tas, beras, dll. ${ }^{10}$

Kegiatan utama dari sebuah lembaga keuangan adalah penyaluran dana dalam pembiayaan, salah satunya adalah penyaluran dana murabahah untuk masyarakat, penyaluran dana ini dilakukan guna membantu masyarakat, adapun salah satu cara untuk menyaluran dana dari masyarakat adalah dengan menyediakan pembiayaan murabahah.

Seharusnya dalam proses akad atau penandatanganan perjanjian murabahah pihak koperasi menjelaskan secara terperinci biaya-biaya apa saja yang dikeluarkan oleh koperasi, namum dalam praktiknya anggota tidak menginginkan proses yang bertele-tele dan merepotkan, anggota menginginkan proses yang cepat seperti Bapak Oma Somali ketika ditanya tentang akad murabahah yang dilaksanakan di koperasi beliau tidak tahu dan hanya mengetahui bahwa beliau meminjam uang untuk modal dagang. ${ }^{11}$

Berdasarkan kesepakatan bersama pihak Koperasi tidak menyediakan barang melainkan hanya menyediakan uang yang diperlukan oleh anggota dengan tambahan akad wakalah dimana anggota membelanjakan uang yang telah diterima sesuai dengan akad yang disepakati. Dalam ijab qabul akad murabahah dengan surat keterangan dimana pihak dalam proses penandatanganan akad disetujui dalam waktu yang bersamaan dengan diawali

\footnotetext{
${ }^{10}$ Wawancara Bapak Entang Saeni, sebagai Bendahara, tanggal 10 Juli 2020

11 Wawancara dengan Bapak Oma Somali, sebagai anggota Koperasi Syariah Masjid Besar Tegalkalong, tanggal 13 Juli 2020.
} 
persetujuan penandatanganan akad murabahah kemudian akad wakalah dilakukan secara lisan dikarenakan pihak koperasi tidak mempunyai contoh surat akad wakalah, selanjutnya proses pencairan dana.

Menurut peneliti ketika akad murabahah dilaksanakan sebenarnya disana belum ada barang yang diperjualbelikan dimana murbahah merupakan jual beli yang harus ada objeknya. Dalam praktik akad murabahah di Koperasi Syariah Masjid Besar Tegalkalong Sumedang Barang yang diperjual belikan hanya ditaksir harga, kualitas dan kuantitasnya sehingga timbulah ketidaksesuaian akad.

b. Mekanisme Pembiayaan Murabahah di Koperasi Syariah Masjid Besar Tegalkalong Adapun mekanisme dalam pembiayaan murabahah di Koperasi Syariah Masjid Besar Tegalkalong yang ditutukan oleh ibu Esih selaku pengelola unit simpanan dan pembiayaan . adalah sebagai berikut:

1) Koperasi Syariah Masjid Besar Tegalkalong hanya melayani dan menerima anggota yang bertempat tinggal di Kecamatan Sumedang Utara dan yang melakukan aktivitas usaha di Kecamatan Sumedang Utara.

2) Untuk bisa mengajukan pembiayaan murabahah maka harus masuk sebagai anggota koperasi dengan membayar biaya pokok sebesar Rp.200.000,- . yang dibayar sekali pada awal hendak masuk sebagai anggota koperasi, biaya pokok tidak bisa diambil selama menjadi anggota namun bisa diambil apabila keluar dari keanggotaan koperasi. Kemudian membayar biaya wajib sebesar Rp. 10.000,- yang di bayar setiap satu bulan sekali.

3) Untuk bisa mengajukan pembiayaan murabahah maka anggota sekurang-kurangnya telah menjadi keanggotaan koperasi selama tiga bulan.

4) Anggota datang ke koperasi dan bertemu dengan pengurus koperasi, kemudian mengajukan besar pinjaman untuk pembelian barang yang kemudian dipertimbangkan oleh pengurus koperasi, pengurus koperasi bertanya tentang penggunaan uang, memberikan kepastian besar dan waktu pencairan kepada anggota. Untuk penetapan margin dari produk akad murabahah di Koperasi Syariah Masjid Besar Tegalkalong ialah sesuai kesepakatan dan kesanggupan anggota, pihak koperasi tidak menuntut batas margin dan waktu angsuran. Bapak Entang Saeni menuturkan ada anggota yang mengajukan biaya pokok sebesar Rp.500.000,- dengan margin Rp.100,000,- adapun yang menyanggupi margin sebesar Rp.50.000,-. Untuk besar cicilan, pihak koperasi menyerahkan kesanggupan kepada anggota asalkan pada waktu jatuh tempo cicilan sudah lunas. Pihak koperasi tidak mematok besar margin begitupun dengan jangka 
waktu angsuran anggota dibebaskan menyepakati waktu namun masih batas normal. Seperti pinjaman sebesar Rp.500.000,- biasanya anggota menyepakati untuk melunasinya selama satu sampai dua bulan. ${ }^{12}$

5) Anggota membawa photocopy ktp tanpa ada jaminan, kemudian pengurus memberitahukan besaran uang yang akan dipinjamkan, marjin yang disepakati dan waktu pelunasan disesuaikan dengan keinginan dan kesanggupan anggota seperti contoh pinjaman atas nama anggota Bapak Oma Somali sebagai berikut:

Pembelian Kebutuhan Warung ( rokok, kopi, dll)

Pokok Pinjaman Rp. 1.000.000,-

Margin Keuntungan Rp. 150.000,-

Jumlah pembiayaan Rp. 1.150.000,-

6) Di sini peran Koperasi tidaklah sebagai penjual tetapi sebagai pihak yang meminjamkan uang untuk anggota. Dalam pembelian barang, anggota melakukannya setelah dana cair. Kedua belah pihak melakukan penandatanganan akad urabahah selanjutnya melakukan akad wakalah secara lisan. Adapun beberapa anggota memberikan kembali nota barang yang dibeli. ${ }^{13}$

Tutur Bapak Bachren Syamsul Bachri selaku Dewan Pengawas, pembiayaan murabahah di Koperasi Syariah Masjid Besar Tegalkalong . ini tidak hanya digunakan untuk biaya produktif saja tetapi ada juga biaya konsumtif semisal untuk biaya kebutuhan rumah ataupun kebutuhan lain. Dari akadnya memang untuk membeli suatu barang, tetapi yang namanya kebutuhan tidak hanya itu saja, ada yang serius untuk membeli ada juga yang tidak, masalahnya apabila akad murabahah sudah disepakati maka pihak koperasi tidak menelisik lagi entah itu untuk apa. ${ }^{14}$

c. Jaminan

Jaminan dalam pembiayaan merupakan hal sangat penting sebagai cara suatu koperasi untuk mengcover apabila terjadi wan prestasi dari anggota. Namun di Koperasi Syariah Masjid Besar Tegalkalong tidak memakai jaminan, hanya memberikan syarat masuk anggota selama minimal tiga bulan baru bisa mengajukan. Bapak Oma Somali membenarkan bahwa dalam Pembiayaan Murabahah di Koperasi Syariah Masjid Besar Tegalkalong memang tidak memakai jaminan. ${ }^{15}$

${ }^{12}$ Wawancara Bapak Entang Saeni, sebagai Bendahara, tanggal 10 Juli 2020.

${ }^{13}$ Wawancara Ibu Esih Sukaesih, sebagai Pengelola Unit Simpanan dan Pembiayaan tanggal 22 Juni 2020.

${ }^{14}$ Wawancara Bapak Bachren Syamsul Bahri, sebagai Dewan Pengawas, tanggal 13 Juli 2020.

${ }^{15}$ Wawancara dengan Bapak Oma Somali, sebagai anggota Koperasi Syariah Masjid Besar Tegalkalong, tanggal 13 Juli 2020. 
d. Utang dalam murabahah

Dalam pembiayaan murabahah di Koperasi Syar'iah Masjid Besar Tegalkalong sampai saat ini beluam ada anggota yang menyampaikan barang dijual kembali dan mengalami kerugian. Jika anggota menjual kembali barang dan mengalami kerugian dari penjualan tersebut, anggota tetap diwajibkan melunasi utangnya sesuai kesepakatan awal.

e. Penyelesaian Kredit Macet

Untuk pembiayaan macet ibu Esih selaku pengurus Koperasi biasanya melakukan pendekatan kepada pihak anggota yang bermasalah, berbicara secara baik-baik kepada anggota untuk datang ke koperasi dan membicarakan tentang waktu pelunasan hutang, apabila tidak ada respon pihak koperasi memberikan surat peringatan. Hasilnya beberapa anggota yang memiliki kredit macet datang ke koperasi untuk meminta keringanan perpanjangan tempo pelunasan dan disetujui pihak koperasi asalkan pinjaman itu lunas. Sedangkan untuk sebagian lagi masih belum ada respon. Pihak koperasi tidak membawa masalah ini ke . jalur hukum dikarenakan masih menunggu respon anggota dan dirasa masih bisa dilakukan dengan bermusyawarah. ${ }^{16}$

\section{f. Bangkrut}

Jika ada anggota bangkrut maka pihak koperasi akan memberi keringanan berupa perpanjangan tempo angsuran namun harus tetap melunasi utangnya. Namun, sampai saat ini belum ada anggota yang mengeluhkan mengalami bangkrut atau pailit. ${ }^{17}$

\section{Kesesuaian Praktik Akad Murabahah menurut Fatwa DSN MUI NO:04/DSN- MUI/IV/2000 Tentang Murabahah di Koperasi Syariah Masjid Besar Tegalkalong Sumedang}

Dari uraian dan penjelasan tentang ketentuan umum fatwa tentang murabahah dan pelaksanaan pembiayaan murabahah di Koperasi Syariah Masjid Besar Tegalkalong bahwa implementasi murabahah yang diterapkan sebagian besar sudah sesuai dengan fatwa DSN MUI No: 04/DSN-MUI/IV/2000 Tentang Murabahah. Namun, bukan berarti implementasi fatwa murabahah .di Koperasi Syariah Masjid Besar Tegalkalong Sumedang tidak lepas dari beberapa penyimpangan, berikut akan penulis uraikan analisis pelaksanaan Akad Murabahah menurut fatwa DSN MUI di Koperasi Syariah Masjid Besar Tegalkalong.

\section{a. Ketentuan Fatwa Pertama}

Pada pembiayaan penyaluran dana di Koperasi Syariah Masjid Besar Tegalkalong dilakukan akad murabahah antara koperasi dan anggota yang didalamnya terdapat penentuan harga jual dan jangka waktu pembayaran cicilan. Akad murabahah ini bebas dari riba karena

\footnotetext{
${ }^{16}$ Wawancara Ibu Esih Sukaesih, sebagai Pengelola Unit Simpanan dan Pembiayaan tanggal 6 Juli 2020.

${ }^{17}$ Wawancara Bapak Entang Saeni, sebagai Bendahara, tanggal 10 Juli 2020.
} 
jangka waktu pembayaran cicilan tidak mempengaruhi total harga barang. Seperti contoh sebagai berikut:

Pembelian Kebutuhan Warung ( rokok, kopi, dll)

Pokok Pinjaman Rp. 1.000.000,-

Margin Keuntungan Rp. 150.000,-

Jumlah pembiayaan Rp. 1.150.000,-

Untuk jangka waktu dan besar angsuran diserahkan sesuai dengan kesanggupan anggota dengan syarat angsuran lunas pada jatuh tempo, sesuai tempo yang disepakati. Meskipun jangka waktu yang disepakati .lama ataupun sebentar besar pinjaman tetap dan tidak bertambah. Dengan begitu membuktikan bahwa jangka waktu pembayaran angsuran atau cicilan tidak mempengaruhi total harga barang yang telah disepakati. Hal ini sesuai dengan ketentuan fatwa pertama pada point ke 1 yang menyebutkan bahwa "Bank dan nasabah harus melakukan akad murabahah yang bebas riba”.

Barang yang diperjualbelikan pada pembiayaan murabahahh di Koperasi Syariah Masjid Besar Tegalkalong yaitu berupa barang-barang kebutuhan rumah tangga seperti beras dan bahan pokok lainnya, barang-barang modal usaha seperti pembelian kebutuhan warung, bahan dagang, dan barang fasilitas dangang seperti showcase, dll. .Barang yang akan dibeli diberitahukan dulu kepada pihak koperasi sehingga barang dipastikan bukan barang haram. Maka hal ini sesuai dengan ketentuan fatwa pertama point ke 2 yakni "Barang yang diperjualbelikan tidak diharamkan oleh syariah Islam”.

Pihak Koperasi Syariah Masjid Besar Tegalkalong membiayai seluruh barang yang diajukan oleh anggota. Hal ini pun sesuai dengan ketentuan fatwa pertama point ke 3 yang menyatakan bahwa "Bank membiayai sebagian atau seluruh harga pembelian barang yang telah disepakati kualifikasinya".

Untuk pengadaan barang yang dibutuhkan anggota, anggota membeli barang tersebut atas nama anggota sendiri karena pembelian sudah diwakilkan kepada anggota sehingga pembelian barang sudah tidak ada sangkutpaut dengan pihak koperasi. Kekurangannya yaitu apabila ada kecacatan atau kerugian barang, pihak koperasi tidak tahu dan tidak ikut mempertanggungjawabkan kerugiannya yang seharusnya itu menjadi tanggungjawab koperasi sebagai penjual. Dalam hal ini tidak sesuai dengan ketentuan fatwa pertama pada point ke 4 yakni "Bank membeli barang yang diperlukan nasabah atas nama bank sendiri, dan pembelian ini harus sah dan bebas riba”. Seharusnya pembelian barang atas nama koperasi sehingga apabila ada kecacatan barang, anggota menyampaikan kepada pihak koperasi sehingga kerugian bisa ditanggung bersama atau sesuai kesepakatan. Hal ini menyebabkan 
ketidakpuasan anggota terhadap peayanan koperasi dikarenakan kerugian hanya ditanggung oleh anggota.

Karena pembelian barang diwakilkan oleh anggota, dan sampai saat ini belum ada anggota yang memberitahukan kepada pihak koperasi bahwa pembelian barang secara utang, dan ini sesuai dengan ketentuan fatwa pertama point ke 5 yang menyatakan "Bank harus menyampaikan seтиa hal yang berkaitan dengan pembelian, misalnya jika pembelian dilakukan secara utang”.

Untuk penyampaiannya pihak anggota yang menjelaskan barang tersebut, barang yang disepakati tersebut kemudian ditentukan harga jualnya dengan perhitungan dari total harga beli di tambah margin yang telah disepakati oleh kedua belah pihak, perhitungan tersebut tertera pada surat perjanjian akad. Sesuai dengan ketentuan fatwa pertama point ke 6 yang menyatakan bahwa "Bank kemudian menjual barang tersebut kepada nasabah (pemesan) dengan harga jual senilai harga beli plus keuntungannya. Dalam kaitan ini Bank harus memberitahu secara jujur harga pokok barang kepada nasabah berikut biaya yang diperlukan”.

Setelah harga jual barang ditentukan dan besarnya angsuran telah disepakati maka anggota membayar dengan jangka waktu sesuai kesepakatan, hal ini pun sesuai dengan ketentuan fatwa pertama point ke 7 yakni "Nasabah membayar harga barang yang telah disepakati tersebut pada jangka waktu tertentu yang telah disepakati”.

Pada pembiayaan murabahah Koperasi Syariah Masjid Besar Tegalkalong tidak ada perjanjian khusus dan tidak ada keharusan sesuai dengan ketentuan fatwa pertama pada point ke 8 yang menyatakan, "Untuk mencegah terjadinya penyalahgunaan atau kerusakan akad tersebut, pihak bank dapat mengadakan perjanjian khusus dengan nasabah”.

Ketika pihak Koperasi Syariah Masjid Besar Tegalkalong melakukan perjanjian murabahah dengan anggota koperasi, dan diwaktu yang sama pihak koperasi mewakilkan kepada anggota untuk membeli barang yang diinginkan sendiri, dan pihak koperasi memberikan kuasa untuk memilih dan menentukan barang yang akan dibeli anggota. Hal ini membuktikan bahwa akad murabahah dilakukan sbelum barang sudah menjadi milik koperasi. Hal ini tentu bertentangan dengan ketentuan fatwa pertama point ke 9 yaitu "Jika bank hendak mewakilkan kepada nasabah untuk membeli barang dari pihak ketiga, akad jual beli murabahah harus dilakukan setelah barang, secara prinsip, menjadi milik bank". Jadi menurut ketentuan berikut jika koperasi ingin memberikan kuasa kepada anggota untuk membeli barang sendiri maka akad murabahah harus dilaksanakan sesudah barang secara prinsip menjadi milik koperasi. Pihak koperasi menggunakan akad wakalah ketika meminta anggota mewakilkan 
koperasi untuk membeli barang dan barang secara prinsip memang menjadi milik koperasi. Namun permasalahannya pihak koperasi menggunakan akad murabahah terlebih dahulu lalu menggunakan akad wakalah. Seharusnya melakukan akad wakalah terlebih dahulu dan ketika barang sudah dibeli oleh anggota dan secara prinsip menjadi milik koperasi, barulah akad murabahah dilakukan.

Adapun alasan pihak koperasi mewakilkan kepada pihak anggota dikarenakan keterbatasan akan pengurus koperasi dan dimaksudkan agar pihak anggota lebih puas dan yakin atas pilihannya sendiri. Akan tetapi alasan tersebut ada plus minusnya, nilai plusnya anggota akan lebih puas dengan pilihannya. Tetapi nilai minusnya, jika terjadi kerusakan atau kecacatan pada barang maka akan menjadi tanggungan pihak angoota dengan pihak pedagang. Hal ini yang akan menimbulkan ketidakpuasan anggota dalam hal pelayanan dari pihak koperasi yang seharusnya semua permasalahan ditanggung bersama.

b. Ketentuan Fatwa Kedua

Untuk ketentuan fatwa kedua point 1 sudah sesuai dengan fatwa DSN yaitu anggota datang ke koperasi dan mengajukan permohonan pembelian barang. Untuk ketentuan fatwa dari point ke 2 "Jika bank menerima permohonan tersebut, ia harus membeli terlebih dahulu aset yang dipesannya secara sah dengan pedagang.", menurut penulis tidak sesuai dengan apa yang dipraktekan pada akad murabahah di Koprasi Syariah Masjid Besar Tegalkalong ini seperti yang sudah dijelaskan di ketentuan fatwa pertama point 9, diantaranya ketika anggota membutuhkan pembiayaan dari koperasi, anggota mengajukan permohonan itu. Anggota sebagai wakil koperasi membeli barang itu sendiri, seharusnya koperasi yang membeli barang yang disepakati secara sah dengan pedagang. Untuk ketentuan fatwa dari point ke 3 sampai 7 dikarenakan barang dibeli oleh anggota maka tidak ada pembatalan pembelian barang.

c. Ketentuan Fatwa Ketiga

Dalam pembiayaan murabahah yang sebenarnya memang tidak ada jaminan dari objek murabahah. Di Koperasi Syariah Masjid Besar Tegalkalong pun tidak memakai jamianan. Jaminan pada dasarnya bukanlah suatu rukun dan syarat yang mutlak yang harus dipenuhi dalam pembiayaan murabahah. Sesuai dengan ketentuan fatwa ketiga point ke 1 dan 2 yang menyatakan "Jaminan dalam murabahah dibolehkan, agar nasabah serius dengan pesanannya.", "Bank dapat meminta nasabah untuk menyediakan jaminan yang dapat dipegang.".

\section{d. Ketentuan Fatwa Keempat}

Untuk ketentuan fatwa keempat point ke 1 sampai ke 3, menurut penulis telah sesuai dengan praktik yang dijalankan oleh pihak Koperasi. Dimana ketika anggota menjual kembali 
barang kepada pihak ketiga walaupun anggota mengalami kerugian dalam penjualan tersebut anggota tetap berkewajiban membayar angsuran kepada koperasi hingga selesai.

e. Ketentuan Fatwa Kelima

Pihak Koperasi Syariah Masjid Besar Tegalkalong pun tidak memaksa anggota untuk melunasi angsurannya segera sebelum masa angsuran berakhir. Namun, anggota pun tidak diperkenankan untuk menunda-nunda pembayaran angsuran kecuali dengan alasan tertentu. Sesuai dengan ketentuan fatwa kelima point ke 1 yakni "Nasabah yang memiliki kemampuan tidak dibenarkan menunda penyelesaian utangnya".

Dan jika anggota tersebut tetap tidak menjalankan kewajbannya pihak koperasi belum melakukan tindakan lebih lanjut untuk dibawa ke Badan Arbitrase Syariah karena dirasa masih bisa diselesaikan dengan musyawarah. Dalam hal ini sudah sesuai dengan ketentuan fatwa kelima point ke 2 yang menyatakan bahwa "Jika nasabah menunda-nunda pembayaran dengan sengaja, atau jika salah satu pihak tidak menunaikan kewajibannya, maka penyelesaiannya dilakukan melalui Badan Arbitrasi Syariah setelah tidak tercapai kesepakatan melalui musyawarah”.

Dalam penyelesaian hutang-piutang antara anggota dan Koperasi Syariah Masjid Besar Tegalkalong, maka hal ini akan difokuskan dalam hal terjadinya wanprestasi atau kelalaian anggota untuk melunasi hutangnya. Kredit macet dalam pembiayaan merupakan suatu permasalahan yang sering terjadi, maka setiap lembaga keuangan termasuk koperasi mempunyai kebijakan-kebijakan yang berbeda. Akan tetapi kebijakan tersebut harus berlandaskan kepada prinsip-prinsip syariah yang telah tertuang dalam fatwa- fatwa DSN.

Berdasarkan hasil penelitian dan wawancara penulis dengan pihak Koperasi Syariah Masjid Besar Tegalkalong, pihak koperasi memberikan beberapa kebijakan dalam menangani kredit macet. Dalam pengambilan keputusan jika terjadi suatu kredit macet, maka pihak koperasi telah mempunyai beberapa langkah yang akan ditempuhnya, diantaranya adalah sebagai berikut :

1) Melakukan proses pendekatan kepada pihak anggota yang bermasalah.

2) Melakukan proses negoisasi jika pendekatan tidak dapat dilakukan. Dalam proses negoisasi ini jika anggota dengan sengaja tidak membayar maka pihak bank akan memberikan surat peringatan (SP) agar anggota bisa datang ke koperasi dan mengajukan keringanan penambahan tempo pelunasan.

3) Jika proses negoisasi sudah tidak dapat dilakukan, untuk saat ini belum ada tindak lanjut lagi dari pihak koperasi dan masih menunggu respon anggota atas surat peringatan yang diberikan. 
Ketidakmampuan anggota dalam melunasi hutangnya tidak selalu mengindentitaskan bahwa nasabah itu sengaja untuk menghindari hutang- hutangnya. Akan tetapi permasalahan tersebut dipengaruhi oleh keadaaan ekonomi di masyarakat yang mengakibatkan keadaaan ekonomi seseorang menjadi terguncang. Menurut peneliti untuk anggota yang memiliki kredit macet seharusnya diberikan kebijakan yang lebih tegas sehingga bisa melunasi utang dan tidak menghambat pada perputaran pembiayaan lainnya.

\section{f. Ketentuan Fatwa Keenam}

Pailit atau bangkrut merupakan hal yang tidak bisa dihindari dari sebuah usaha. Pihak koperasi tidak menyulitkan anggota yang memang benar benar belum bisa menyelesaikan angsurannya apalagi jika mengalami kebangkrutan. Pihak koperasi biasanya memberikan kebijakan perpanjangan tempo angsuran. Hal ini sesuai dengan fatwa keenam yaitu "Jika nasabah telah dinyatakan pailit dan gagal menyelesaikan utangnya, bank harus menunda tagihan utang sampai ia menjadi sanggup kembali, atau berdasarkan kesepakatan".

\section{KESIMPULAN}

Umumnya Praktik Akad Murabahah di Koperasi Syariah Masjid Besar Tegalkalong sudah sesuai dengan Fatwa DSN MUI NO:04/DSN-MUI/IV/2000 Tentang Murabahah. Namun ada 2 (dua) point ketentuan fatwa tentang murabahah yang belum sesuai dengan praktik yang dijalankan oleh pihak Koperasi Syariah Masjid Besar Tegalkalong. Yaitu Pembelian barang diwakilkan oleh anggota oleh anggota, anggota pun membeli barang atas nama sendiri bukan atas nama koperasi, dan ini tidak sesuai dengan fatwa pertama point 4 yang menyatakan "Bank membeli barang yang diperlukan nasabah atas nama bank sendiri, dan pembelian ini harus sah dan bebas riba”. Ketika pihak koperasi melakukan akad murabahah dan diwaktu yang sama pihak koperasi melakukan akad wakalah dikarenakan pembelian barang diwakilkan oleh anggota dan anggota membeli barang yang telah disepakati sendiri, hal ini berarti akad murabahah dilaksanakan sebelum barang menjadi milik koperasi. Hal ini jelas bertentangan dengan ketentuan fatwa pertama point 9 yaitu "Jika bank hendak mewakilkan kepada nasabah untuk membeli barang dari pihak ketiga, akad jual beli murabahah harus dilakukan setelah barang, secara prinsip, menjadi milik bank".

\section{REFERENSI}

Azzam, Abdul Aziz Muhammad. 2010. Fiqh Muamalat. Jakarta : Amzah

Dewan Syariah Nasional, 2000, Fatwa Dewan Syariah Nasional Tentang Murabahah, Jakarta, Fatwa DSN-MUI No. 4 
Fitri Syifa Fauziah, 2020. "Praktek Akad Murabahah di Koperasi Syariah Masjid Besar Tegalkalong" Hasil Wawancara Pribadi: Juli 2020, Sumedang.

Kautsar Riza Salman, 2014, . Akuntansi Perbankan Syariah Berbasis PSAK Syariah, Jakarta: Akademia Permata.

Nurhadi, . 2017, Filsafat Hukum Islam Akad Kompilasi Hukum Ekonomi Syariah (Analisis Maqashid Syariah Buku II Tentang Akad) (Jurnal AlAmwal Vol. 6, No. 2.

Rahmat Syafei, 2001, Fiqh Mu'amalah, Bandung: Pustaka Setia.

Sugiyono. 2014, Metode Penelitian Pendidikan: Pendekatan Kuantitatif, . Kualitatif, . .Dan R\&D. Bandung: Alfabeta.

Syamsul Anwar, 2007, Hukum Perjanjian Syariah, Jakarta, Rajagrafindo Persa.

Sri Nurhayati dan Wasilah, 2014, Akuntansi Syariah di Indoensia Edisi 3 Jakarta, Salemba Empat.

Yin, Robert K, 2006, Studi Kasus; Desain dan Metode, Jakarta, PT. Raja Grafindo.

https://www.kompasiana.com/achmadmaulanarizqi0429/5de01353097f3616876ece52/bukanhal-aneh-tapi-kenapa-pembiayaan-murabahah-banyak-diminati-diindonesia?page=all\#sectionall Diakses pada tanggal 15 April 2020 pukul 21.00. 